\title{
Methods to Strengthen the Construction of Academic Atmosphere in Colleges and Universities in the New Media Era
}

\author{
Ning Zhang \\ University of Electronic Science and Technology of China \\ Chengdu, China 611731
}

\begin{abstract}
In the new media era, colleges and universities face many difficulties and challenges in the construction of academic atmosphere. This paper probes into the problems existing in the construction of the academic atmosphere in colleges and universities, finds out the new ideas of constructing the fine academic atmosphere, advocates that the student workers in colleges and universities renew their educational ideas, relies on and makes use of the new media technology, and carries out the construction of the academic atmosphere in colleges and universities from the aspects of atmosphere construction, teaching reform, school-enterprise cooperation and so on.
\end{abstract}

Keywords—new media era; academic atmosphere construction; teaching reform; school-enterprise cooperation

\section{INTRODUCTION}

What is academic atmosphere? Academic atmosphere refers to the stable and inclined learning attitudes and habits shown by students collectively or individually in the learning process. [1] However, with the popularity of the Internet and mobile intelligent terminals, the ideological content, living habits and even learning methods of young students are quietly changing, which has a great impact on the learning atmosphere of college students. It is well known that a good style of study is an important cornerstone for colleges and universities to cultivate excellent talents and realize sustainable development. In the era of new media, how to rely on and use new resources to comprehensively implement the fundamental tasks of morality education, and establish a good style of study is an urgent problem to be solved in higher education.

\section{PROBlems EXISTING IN THE CONSTRUCTION OF ACADEMIC ATMOSPHERE IN COLLEGES AND UNIVERSITIES IN THE NEW MEDIA ERA}

\section{A. New Media Dilute the Learning Atmosphere in Colleges and Universities}

There are more and more phubber in the campus. They either shake their heads with their headphones, or stare at the screen of the mobile phone without raising their heads. Even in college classrooms, students browse the web, scan Weibo, and chat on WeChat, completely immersed in their mobile phone world, and deaf to classroom teaching. In the new media era, entertainment and games occupy a lot of time for young students. Some students are distracted in classroom teaching, while others seriously lead to the disorder of work and rest time, which not only affects the teaching quality of colleges and universities, but also destroys the original strong learning atmosphere on campus.

\section{B. Incorrect Attitudes Brought by New Media}

In the era of new media, the acquisition of knowledge becomes more convenient, students need to correct their learning attitude, and teachers need to understand the real connotation of education.

With the popularity of the Internet, books and classrooms are no longer the only way for students to acquire knowledge, and many search engines can freely query what they want to know. The inertia of learning began to breed among young students. In class, they relied on search to deal with questions, after class, they relied on search to deal with homework, and the summary report was copied from the Internet. In the process of searching, college students gradually lose their initiative and innovation in learning, as well as their clear learning goals and rigorous academic attitude.

In contrast, college teachers, many teachers think that their task is to teach, explain the learning content and professional knowledge in books, and ignore the daily performance of students such as early leave, late arrival, inattention and other classroom chaos. Teachers only pay attention to teaching and neglect education, and their teaching attitude is not strict, which is another important reason that affects the construction of academic atmosphere in colleges and universities.

\section{Students Lack the Ability to Practice Under the Wave of New Media Information}

Young students immersed in the Internet world, through the Internet to recognize the world, exchange views. The knowledge they obtain through search engines is imperfect, one-sided, fragmented, and lacks the systematicness and completeness of knowledge. The scientific and cultural knowledge of college students should finally be applied to practice and specific social work. After all, the income in the virtual world can't meet the needs of the real world. When the two are connected, when young students go to work, students 
will find that they lack the applied understanding of knowledge, and their practical ability needs to be improved.

\section{RELYING ON NEW MEDIA TO STRENGTHEN THE CONSTRUCTION OF ACADEMIC ATMOSPHERE IN COLLEGES AND UNIVERSITIES}

\section{A. Skillfully Using New Media to Create a Full Learning Atmosphere}

New media is a double-edged sword, which brings many problems and challenges to colleges and universities, but also brings new opportunities for the reform and development of education. Campus culture provides a necessary carrier for the development of academic atmosphere in colleges and universities, and a good atmosphere of campus culture can guide and promote the style of study in colleges and universities.[3] In the new media era, colleges and universities should rely on and make use of new media resources to enrich the connotation and extension of campus culture.

Colleges and universities should accept the diverse and strong cultural and spiritual needs of students, skillfully use new media to effectively stimulate students' enthusiasm for learning activities, and create a learning atmosphere for all students. For example, the challenge of getting up early in 21 days the English word punch-in program, the peer-to-peer competition, and so on, so that the young students can restrain their behavior habits, plan their learning goals in the long run, and stimulate their fighting spirit and learning competition consciousness with the assistance of smart phones.

The national university early punch-in plan jointly initiated by Tencent micro-school, pocket college and national college wechat public platform is called the 21 Days of Decisive Battle. It calls on college students to get up at 5-9 a.m. every day to punch-in in the App to accumulate positive learning energy. [4] Students can record their summer vacation study plans on the APP every day to form an effective information flow and list. Young students who are involved in the program can see the life and learning dynamics of students all over the country. They can also invite friends to compete with each other and accumulate energy for their own school at the same time.[4] Introduce the competition mechanism with fun games, comprehensively stimulate the competition consciousness of young students, the competitive motivation can be formed to drive the learning atmosphere.

The atmosphere of full-learning is in line with the educational concept of "three-wide education", and all colleges and universities are encouraged to participate in the construction of study style, including students, counselors, professional teachers, managers and logistic service personnel. The counselors lead the thinking, the professional teachers preach and solve the puzzles, the management personnel update the system, the logistics personnel beautify the environment, the students learn spontaneously and consciously, all of them work together to improve the new media literacy, form the correct media concept, help the students develop good network behavior habits, and create a strong learning atmosphere in colleges and universities.

\section{B. New Media into the Classroom to Promote All-round Teaching Reform}

The emergence of new media has brought a full impact to traditional teaching methods. Students are bored with teachers repeat what the book says on the platform. Many students cannot accept the boring teaching mode in large classes. Their attention is more easily attracted by dynamic and lively video and audio. This requires college workers to update their education concepts in a timely manner and introduce rich and interesting new media education technologies into the classroom.

Colleges and universities should start from both students and teachers, cultivate a good learning atmosphere and teaching style, and form an excellent learning atmosphere that has a cohesive effect on all faculty and staff, a mentoring effect on young students, and a demonstration effect on society.

When new media technology enters the classroom, it is no longer only taught by the teacher and passively accepted by the students, but into the interaction between teachers and students, combining rigorous academic knowledge with interesting language, so that hearing and vision jointly arouse students for knowledge. The emergence of new forms such as online public lessons and live video lessons enables students to study anytime, anywhere and acquire knowledge in a fresh way. MOOC for Chinese college students is a high-quality online learning platform in China, which is jointly built by icourses and cloud classroom of Netease. At present, the platform has more than one thousand courses offered by more than one hundred colleges and universities, which are deeply loved by young college students.

The new media covers students' life outside the classroom, carries out comprehensive and multi-dimensional education work, and breaks down the education work into all aspects of the student's learning life to form a comprehensive education. Educators no longer lock their teaching goals and tasks in the first classroom. They use new media technologies such as Weibo, Bilibili, WeChat official account and other new media technologies that young students like to carry out multidimensional teaching activities. Colleges and universities should actively promote the application of online new media platforms such as ideological and political counselor blogs, professional theory course teacher blogs, and campus official micro-blogs, so as to create a high quality blog group with the academic charm and personality charm of famous teachers, gather the ideological sparks of scholars and experts, and display the elegant demeanor of famous teachers.[5] The blog of Ideological and political counselors in colleges and universities has become an important work platform for education and service of students. It can realize the communication between teachers and students across time and space, even anonymous communication, which is equal, timely and diverse.

New media platform not only enriches the connotation of education, but also brings a new teaching reform. It extends education to after class, the lives of students and even into entertainment. We advocate that college teachers rely on rich Internet resources to use their positive forces to subconsciously guide and influence the young students around them, to be 
close friends in student life, and life mentors in growth. In the era of new media, all efforts should be made to build an excellent academic atmosphere that is of great cohesion to the faculty and staff, edifying to the young students, and exemplary to the society.

\section{Spreading the Concept of School-enterprise Cooperation Education with the Help of New Media}

It should be understood how to awaken students from the virtual world of the network, so that they can master professional knowledge completely and systematically, and can better apply what they have learned to the actual work in the future. Schools train talents and enterprises need talents. School-enterprise cooperation is an employment-oriented innovative talent training model. It highly matches the rich teaching and $\mathrm{R} \& \mathrm{D}$ resources of colleges and universities with the talent chain and industrial chain of the enterprise, and the colleges and universities take famous teachers as the core to create a professional teacher learning teams, the enterprise takes excellent engineer as the core to build excellent practice team.[6] Famous teachers in colleges and universities and enterprise engineers set up teams to jointly cultivate the scientific and technological knowledge and practical ability of young students, so that colleges and universities can cultivate the compound talents needed by the society and favored by enterprises.

With the help of the influence and communication speed of the new media, more young students can participate in the school-enterprise cooperation project, pay attention to the subject creation competition jointly organized by the enterprise and the university. Through professional skills competition, students can feel the importance of theoretical knowledge guide the practice operation more truly, and let the excellent students team grow up constantly in the competition, feel the fun and sense of achievement brought by learning. At the same time, invite industry experts, well-known entrepreneurs and other long-distance video and online Q \& A, so that students understand the development trend of the industry and adjust the learning direction in time. At present, many enterprises began to enter the campus to set up a joint training base, this kind of educational concept of school-enterprise cooperation has also been widely recognized by the society.

"Robomaster Robot Master Competition", "Siemens Automation Challenge Competition" and "Ti Electronic Design Competition" are all scientific innovation competitions for college students carried out by enterprises in various colleges and universities. With the help of new media resources, these competitions spread rapidly on major portal websites, live video platforms and campus BBS forums. More and more young students pay attention to the science and technology events hosted by enterprises through mobile phone clients, understand the educational concept of schoolenterprise cooperation, actively participate in the enterprise internship training project through online registration, so as to truly apply their professional knowledge to science and technology practice.

School-enterprise cooperation is a bridge, which enables students to walk out of the ivory tower and really realize what kind of talents enterprises need, so that students can learn scientific and cultural knowledge spontaneously, independently and consciously. Schools and enterprises build practical teaching platform through new media technology, match teaching power, create co-construction, co-management and co-education of talent training model, significantly improve the quality of talent training, and realize the directional and accurate training of talents.[6] Colleges and universities can and should make the construction of academic atmosphere be built with the assistance of new media technology to spread the new educational idea of schoolenterprise cooperation.

\section{CONCLUSION}

The academic atmosphere is the concentrated embodiment of the spirit of the colleges and universities, the foundation of the university and the soul of its development. As an important carrier of communication between universities and society, new media has a close relationship with college students. It is an important reference for the ideological dynamic, learning styles and living habits of college students, and plays an important role in the construction of academic atmosphere in colleges and universities. [7] It is necessary to dialectically view the opportunities and challenges brought by new media to education. Based on the ever-changing educational realities, reasonably carry out the construction of the academic atmosphere in colleges and universities, advocate the educators in colleges and universities to actively study the knowledge of new media, master the law of the dissemination and development of new media, and rely on and make use of new media to build an excellent academic atmosphere in colleges and universities. Stimulate the competition consciousness of young students through the new media APP to drive the learning atmosphere; Relying on the new media technology to promote the teaching reform, both online and offline dual track parallel, carrying out education work in imperceptible influence; With the speed of new media dissemination, develop the school-enterprise cooperation concept of education, and jointly build a practical teaching platform. Colleges and universities should keep pace with the time, seize the opportunity brought by new media technology, and carry out the construction of academic atmosphere in colleges and universities innovatively.

\section{REFERENCES}

[1] Wu Linlin. Challenges and Countermeasures for the Construction of Academic Atmosphere in Colleges and Universities in the New Media Era [J]. Youth era, 2015 (22) (in Chinese)

[2] Gao Aifang, Gao Weisong. Investigation and Analysis on the Use of New Media by College Sudents and Moral Education Guidance [J]. Research in Ideological and Political Education, 2010, 26 (1) 32-134. (in Chinese)

[3] Chen Huafeng, Zhang Cuiling, Wang Jijian. Research on the Impact of New Media on the Construction of Study Style in Colleges and Universities and Its Application Countermeasures [J]. Learning Weekly, 2014 (12). (in Chinese)

[4] Sohu webpage "21 Days of Decisive Battle" https://www.sohu.com/a/162681195_684229. (in Chinese)

[5] Shi Zhicheng. Investigation on the Current Situation of Classroom Culture Construction in Universities in the Era of Media and the 
Countermeasures [J]. Journal of Hubei University of Economics (Humanities and Social Sciences), 2017, 14 (1): 150-153. (in Chinese)

[6] Shan Min. Exploration of Continuing Education Model Based on School-Enterprise Cooperation [J]. Industry and Science Forum, 2015 (17). (in Chinese)

[7] Zhang Chunyan, Li Fanfan, Zhang Yizhen. Influence of New Media on the Construction of Academic Atmosphere in Colleges and Its Countermeasures [J]. New Media Research, 2018 (5). (in Chinese) 